\title{
Developmental Potential of Quail Dorsal Root Ganglion Cells Analyzed in vitro and in vivo
}

\author{
H. Rohrer, ${ }^{*}$ A. L. Acheson, ${ }^{\star}$ J. Thibault, $\dagger$ and H. Thoenen* \\ *Max-Planck-Institute for Psychiatry, Department of Neurochemistry, D-8033 Martinsried, Federal Republic of \\ Germany, and TCollège de France, Paris, France
}

\begin{abstract}
The cell types present in quail dorsal root ganglia during early development were identified using markers for neurons, glial cells, and fibroblasts (Rohrer et al., 1985). Using the quailchick transplantation technique, the potential of quail dorsal root ganglion cells to differentiate to adrenergic chromaffin cells, as identified by tyrosine hydroxylase immunostaining, was analyzed. A population of undifferentiated cells, which is present in quail dorsal root ganglia at embryonic day 5, was separated from neurons and glial cells. We show that this population contains cells that differentiate to adrenergic chromaffin cells after back-transplantation into 2-d-old chick embryos. A large proportion of these undifferentiated cells also differentiates to neurons in vitro. Precursors for adrenal chromaffin cells and for neurons are present in dorsal root ganglia in significant numbers only during early development.
\end{abstract}

During the development of the PNS, the neural crest-derived cells that ultimately form a specific type of peripheral ganglion have not been irreversibly determined to differentiate to the phenotypes specific for that ganglion. For instance, environmental influences are able to induce the properties of cholinergic neurons in adrenergic neurons (Landis and Keefe, 1983; Patterson, 1978). It has also been demonstrated that cells from sensory ganglia or cholinergic (ciliary) ganglia are able to differentiate to adrenergic neurons and chromaffin cells after these ganglia have been back-transplanted into early embryos (for review, see I eDouarin, 1984). However, in these experiments, the non-neuronal cells, rather than postmitotic neurons, were shown to have responded to the altered environment by acquiring an adrenergic phenotype (Ayer-LeLievre and LeDouarin, 1982; Dupin, 1984). In previous studies we have identified the cell types present in chick dorsal root ganglia (DRG), using the O4 antigen (Sommer and Schachner, 1981) as a marker for glial cells, tetanus toxin and the Q211 antigen (Henke-Fahle, $1983 \mathrm{a}$, b) as markers for neurons, and fibronectin as a marker for fibroblasts and endothelial cells. We have quantified the appearance of these cell types in DRG during development (Rohrer et al., 1985). It was demonstrated that a population of undifferentiated cells is present in the DRG until embryonic day (E) 7 that contains neuronal progenitor cells (Rohrer et al., 1985). The present study was undertaken to test the developmental potential of this undifferentiated cell population in vivo using the quail-chick transplantation technique (LeDouarin, 1973; LeDouarin et al., 1978; LeLievre et al., 1980). We have now quantitatively analyzed the distribution of cell types present in quail DRG, and we have investigated the potential of these

Received Dec. 6, 1985; revised Feb. 20, 1986; accepted Feb. 24, 1986

We thank L. Stegmann for excellent technical assistance, and $H$. Thorun, F. Scholz-Marb, and S. Saadat for their help in the production of the monoclonal antibodies.

Correspondence should be addressed to Hermann Rohrer at the above address. Copyright 1986 Society for Neuroscience 0270-6474/86/092616-09\$02.00/0 cells to differentiate to adrenergic chromaffin cells. We demonstrate that precursors of adrenergic chromaffin cells are present in significant numbers only during early development, when a population of undifferentiated cells is present in these ganglia. This cell population was separated from neurons and glial cells; back-transplantation then directly demonstrated that this population contained precursors for adrenergic chromaffin cells. About $30 \%$ of these undifferentiated cells also differentiated to neurons in culture. A preliminary report of this work has appeared previously (Rohrer et al., 1984). (The term "precursors for adrenal chromaffin cells" is used operationally for cells that are capable of differentiating to adrenal chromaffin cells. We do not want to imply that these cells are normally destined to differentiate as chromaffin cells.)

\section{Materials and Methods}

\section{Cell culture}

DRG were dissected from the lumbosacral region of quail embryos at various ages, cleaned carefully from the surrounding tissue, and dissociated after trypsinization as described previously (Barde et al., 1980, 1982). The cells were plated at a cell density of 80,000 cells $/ 35 \mathrm{~mm}$ culture dish. For short-term $(3 \mathrm{hr})$ cultures, cells were kept on a polyornithine-coated dish in F14 medium supplemented with $10 \%$ ( $\mathrm{vol} / \mathrm{vol})$ heat-inactivated horse serum (Rohrer et al., 1985). Twenty-four-hour cultures were kept on a laminin-polyornithine-coated dish in the same medium, which was further supplemented with NGF $(10 \mathrm{ng} / \mathrm{ml})$ and $200 \mathrm{ng} / \mathrm{ml}$ brain-derived neurotrophic factor (BDNF; Barde et al., 1982; for details see Rohrer et al., 1985). Between 90 and $100 \%$ of the cells attached after $3 \mathrm{hr}$ survived for $24 \mathrm{hr}$ under the present culture conditions at all embryonic stages analyzed. Explant cultures were carried out on collagen-coated dishes in modified Eagle's medium supplemented with $10 \%$ horse serum, $10 \%$ chick embryo extract, NGF (10 $\mathrm{ng} / \mathrm{ml})$, and BDNF (200 $\mathrm{ng} / \mathrm{ml})$.

\section{Immunofluorescent staining of cultures}

Cell-surface antigens were visualized in cultures of DRG cells by indirect immunofluorescent staining of live cultures as described in detail previously (Rohrer, 1985; Rohrer et al., 1985). The cultures (either 3 or $24 \mathrm{hr}$ in culture) were first incubated with antibodies against the $\mathrm{O} 4$ antigen, Q211 antigen, or fibronectin or with tetanus toxin. Cultures that had been labeled with tetanus toxin were subsequently incubated with human anti-tetanus toxin antiserum. After incubation with the cell-type-specific antibodies (or toxin and anti-toxin antiserum), cells were fixed with $4 \%$ paraformaldehyde and incubated with FITC-labeled secondary antibodies. Cultures were then washed, mounted in PBS/ glycerol $(1: 1, \mathrm{vol} / \mathrm{vol})$ and viewed with a Leitz Orthoplan microscope using epifluorescence UV illumination. Tetanus toxin was a gift from Dr. B. Bizzini, Institut Pasteur, Paris. O4 antibodies and Q211 antibodies were generously provided by $\mathrm{M}$. Schachner, Institute for Neurobiology, University of Heidelberg, and S. Henke-Fahle, Max-PlanckInstitute for Developmental Biology, Tübingen.

Complement-mediated cell lysis using Q211 and 04 antibodies Cells from dissociated DRG were incubated for $40 \mathrm{~min}$ at $37^{\circ} \mathrm{C}$ with guinea pig complement (1:6) and either $\mathrm{O} 4$ antibody (1:40) or Q211 
antibody (1:1000) or both antibodies, as described in detail previously (Rohrer et al., 1985). After incubation, cells were collected by centrifugation and washed once in culture medium. Cells were then either plated or repelleted by centrifugation and embedded in a plasma clot as described below.

\section{Transplantation}

DRG from quail embryos were carefully dissected at the lumbosacral region. Before taking out the DRG, the ventral part of the vertebra, sympathetic ganglia, and spinal cord were removed. By sectioning 5-dold quail embryos and staining for tyrosine hydroxylase (TH) immunoreactivity, we checked that the sympathetic ganglia were completely removed by this dissection procedure, while DRG were left intact for later dissection. These control experiments also demonstrated that lumbosacral DRG in quail and chick embryos are devoid of TH-positive neurons. Depending on the size of the ganglia, one-half or one-quarter of a ganglion was implanted. The ganglia or plasma clots containing purified populations of cells wcre implanted between neural tube and somite of 2-d-old chick embryos (21-24 somite embryos) at the adrenomedullary level following the method of LeDouarin et al. (1978). In order to implant cell suspensions from dissociated ganglia, these cells were embedded into a plasma clot: Cell suspensions were collected by centrifugation $(10 \mathrm{~min}, 70 \times g)$ in a conical tube. The cell pellet was mixed with $1 \mu \mathrm{l}$ of hen plasma and $0.5 \mu \mathrm{l}$ of a thrombin solution $(3 \mathrm{mg} /$ $\mathrm{ml}$ in $\mathrm{F} 14$ ). Within $5 \mathrm{~min}$ at $37^{\circ} \mathrm{C}$ a plasma clot had formed, and this was transferred to a culture dish containing Tyrode's solution. For implantation the plasma clot was cut into small pieces using iridectomy scissors.

\section{Production of monoclonal antibodies against TH}

Female BALB/c mice were immunized with purified TH from rat pheochromocytoma tumor (Thibault et al., 1981). After a first intradermal injection with Freund's incomplete adjuvant, 2 intradermal injections with Freund's complete adjuvant were given every 3 weeks using 20 $\mu \mathrm{g}$ of purified $\mathrm{TH}$ for each injection. Ten days after the second boost, the animals were producing antibodies against rat $\mathrm{TH}$, as shown by a dot-immunobinding assay according to Hawkes et al. (1982). The last $4 \mathrm{~d}$ prior to fusion, the animals received daily intraperitoneal injections of the antigen using antigen in Freund's incomplete adjuvant on the first day and antigen in PBS on the following days. The spleen cells were fused with $\mathrm{Ag} 8.653$ myeloma cells according to published procedures (Gooding, 1980) using polyethylene glycol 1500 (Boehringer, Mannheim).

After $8 \mathrm{~d}$ the screening was carried out for the TH antigen using the dot assay (Hawkes et al., 1982). Positive clones were further screened by indirect immunoprecipitation of TH. Homogenates from bovine adrenal chromaffin cells were incubated with a complex of goat antimouse immunoglobulin (Bioscience Products) and protein-A Sepharose beads (Pharmacia) that was bound to the hybridoma supernatants. After incubation for $2 \mathrm{hr}$ at $4^{\circ} \mathrm{C}$ on a shaker, the TH activity was assayed in the supernatant. The TH assay was performed as described in detail by Acheson et al. (1984). In addition, sections of chick and quail adrenals were stained using 1:1 diluted hybridoma supernatants and the protocol described below. Five positive clones were obtained and recloned twice by limiting dilution. The clone $2 / 40 / 15$ was selected since it gave the strongest immunostaining. Hybridomas were cultured in a medium consisting of Dulbecco's modified Eagle's medium containing $4 \mathrm{~g} /$ /iter glucose supplemented with $15 \%$ fetal calf serum. Antibodies were concentrated 25 times by precipitation with $50 \%\left(\mathrm{NH}_{4}\right)_{2} \mathrm{SO}_{4}$.

\section{Immunoblotting}

SDS-PAGE and transfer onto nitrocellulose were as follows: Whole quail, chicken, and rat adrenal glands, rat kidney, and bovine adrenal medullary tissue werc homogenized in 10 vol of sample buffer-62.5 $\mathrm{mm}$ Tris $\mathrm{HCl}, \mathrm{pH} 6.8,2.25 \%$ (wt/vol) SDS, $5 \%$ (vol/vol) 2-mercaptoethanol, $15 \%$ (vol $/ \mathrm{vol}$ ) glycerol, and $0.01 \%$ (wt/vol) bromphenol blueusing a glass/glass homogenizer. The resulting extracts were heated to $100^{\circ} \mathrm{C}$ for $3 \mathrm{~min}$. Equal volumes of the extracts were then subjected to vertical slab gel electrophoresis using the discontinuous buffer system described by Laemmli (1970), with a 3.75\% stacking gel and a $10 \%$ separating gel. Following electrophoresis, proteins were immediately transferred to nitrocellulose paper (Towbin et al., 1979) using a BioRad Trans-Blot apparatus. Transfer was at $0.25 \mathrm{~A}$ for $24 \mathrm{hr}$.

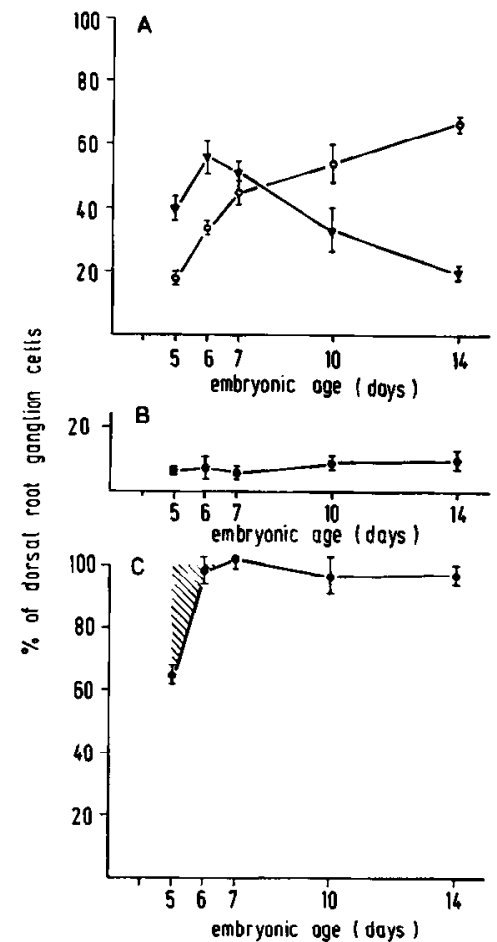

Figure 1. Proportion of neurons, glial cells, and fibroblasts in quail DRG during development. $A$, DRG were dissected from embryos at the ages indicated, dissociated to single cells, and analyzed for the percentage of $\mathrm{O} 4$ antigen-positive cells $(\mathrm{O})$ and tetanus toxin-positive cells $(\nabla)$ after $3 \mathrm{hr}$ in culture. Data are expressed as the means \pm SEM of triplicate determinations. $B$, After $1 \mathrm{~d}$ in culture the proportion of fibronectin-positive cells ( $)$ was determined. Data are expressed as the means \pm SEM of triplicate determinations. $C$, Proportions of neurons, glial cells, and fibroblasts summed for every age. Dashed area indicates the presence of cells devoid of the cell-type-specific markers.

\section{Localization of immunoreactive bands on the nitrocellulose}

The nitrocellulose was first blocked by incubation with $10 \mathrm{~mm}$ Tris $\mathrm{HCl}$, pH 7.4 , containing $150 \mathrm{mM} \mathrm{NaCl}, 2.5 \% \mathrm{BSA}, 0.25 \%$ gelatin, and $0.3 \%$ Tween- 20 at $40^{\circ} \mathrm{C}$ for $1 \mathrm{hr}$ and then at room temperature for an additional $1 \mathrm{hr}$. The nitrocellulose was then incubated overnight at $4^{\circ} \mathrm{C}$ with the anti-TH monoclonal antibodies, $\left(\mathrm{NH}_{4}\right)_{2} \mathrm{SO}_{4}$ concentrate diluted

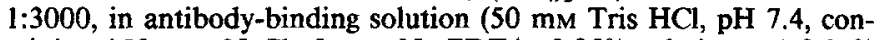
taining $150 \mathrm{mM} \mathrm{NaCl}, 5 \mathrm{mM} \mathrm{Na}$ EDTA, $0.25 \%$ gelatin, and $0.05 \%$ Nonidet, $\mathrm{P}-40$ ) with continuous shaking. Filters were then washed once with water and twice with wash solution $(50 \mathrm{~mm}$ Tris $\mathrm{HCl}, \mathrm{pH} 7.4$, containing $500 \mathrm{mM} \mathrm{NaCl}, 5 \mathrm{~mm} \mathrm{Na} \mathrm{N}_{2}$ EDTA, $0.25 \%$ gelatin, and $0.4 \%$ sarkosyl) prior to incubation with the second antibody (Rat anti-mouse covalently coupled to HRP, 1:1000 in antibody-binding solution) for 2 $\mathrm{hr}$ at room temperature. The nitrocellulose was then washed 5 times with wash solution and once with water; the color development of the peroxidase reaction was then carried out for $25 \mathrm{~min}$ at room temperature in $50 \mathrm{~mm}$ Tris $\mathrm{HCl}$, pH 7.4, containing $200 \mathrm{mM} \mathrm{NaCl}$ using $0.05 \%$ 4chloro-1-naphthol and $0.01 \% \mathrm{H}_{2} \mathrm{O}_{2}$ as substrates. Nitrocellulose sheets were then washed with water and stained for protein using Ponceau $\mathrm{S}-$ $0.2 \%(\mathrm{wt} / \mathrm{vol})$ in $3 \% \mathrm{TCA}$.

\section{Immunocytochemical staining of TH-containing cells in chick or quail adrenals.}

Suprarenal glands were dissected from E13-E15 chick or quail embryos and fixed for $2 \mathrm{hr}$ at $4^{\circ} \mathrm{C}$ using $4 \%$ paraformaldehyde in $0.1 \mathrm{M}$ phosphate buffer, $\mathrm{pH}$ 7.3. The fixed tissue was kept overnight in $30 \%$ sucrose. Cryostat sections $(5 \mu \mathrm{m})$ were cut at $-20^{\circ} \mathrm{C}$ and dried on gelatin-coated glass coverslips. The sections were rehydrated for $30 \mathrm{~min}$ in a $0.01 \mathrm{M}$ Na-phosphate buffer, pH 7.4, supplemented with $0.5 \mathrm{M} \mathrm{NaCl}, 0.7 \%$ carrageenan (Sigma C-3889 Type IV), 0.2\% Triton X-100, and $0.01 \%$ azide (buffer $A$ ). Subsequently, the sections were incubated with mouse 

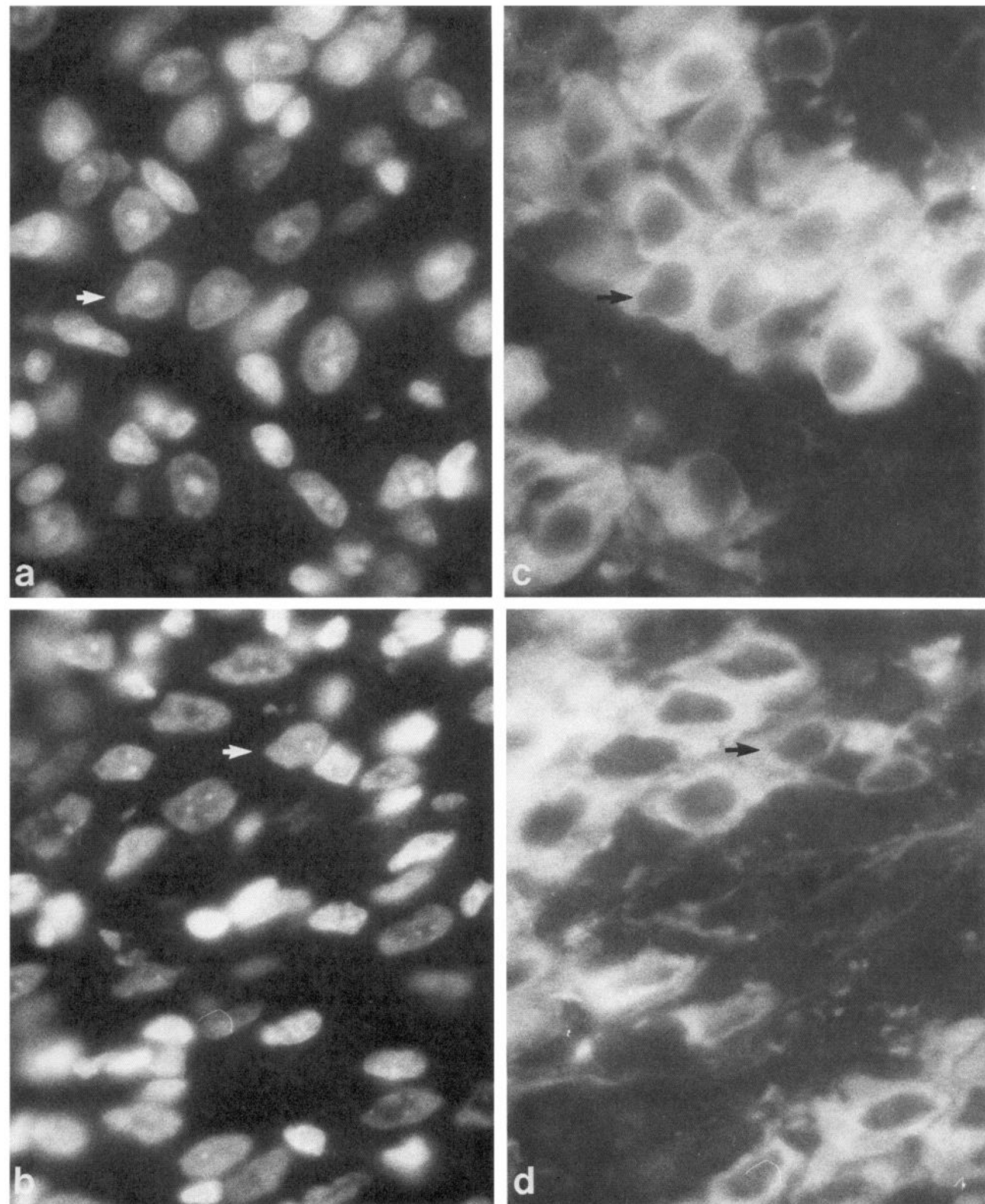

Figure 2. Combination of nuclear DNA staining and immunostaining for TH. Frozen sections from quail $(a, c)$ and chick $(b, d)$ adrenal glands were simultaneously stained with the fluorescent dye Hoechst 33258 and with mouse monoclonal antibodies against $\mathrm{TH}$. Bound antibodies were detected with FITC-labeled secondary antibodies. Fluorescent DNA staining $(a, b)$ and FITC-staining $(c, d)$ were visualized using appropriate filter combinations. Arrows indicate nuclei that can be assigned to TH-positive adrenal chromaffin cells. Magnification, $\times 1300$.

monoclonal anti- $\mathrm{TH}$ antibodies, $\left(\mathrm{NH}_{4}\right)_{2} \mathrm{SO}_{4}$ concentrate diluted 1:1000 in buffer A) overnight at room temperature in a water-saturated atmosphere. The sections were then washed twice for 10 min with Trisphosphate buffer, pH 7.8 (buffer B: $55 \mathrm{~mm} \mathrm{Na}_{2} \mathrm{HPO}_{4} \times \mathrm{H}_{2} \mathrm{O}, 15 \mathrm{~mm}$
$\mathrm{KH}_{2} \mathrm{PO}, 0.6 \mathrm{M} \mathrm{NaCl}, 0.21 \mathrm{M}$ Tris $\mathrm{HCl}, 0.02 \%$ azide), once with buffer $A$, and twice again with buffer $B$ for 10 min each time. Afterward, the sections were incubated for $2 \mathrm{hr}$ at room temperature with FITC-labeled antibodies against mouse or rabbit immunoglobulins (1:100; Miles), 
washed again as described above, and mounted in PBS/glycerol (1:1). For the simultaneous staining of TH and nuclei, the sections were incubated for $30 \mathrm{~min}$ with the fluorescent dye Hoechst 33258 (Serva, Heidelberg), $1 \mu \mathrm{g} / \mathrm{ml}$ in buffer B, after the treatment with FITC-labeled antibodies. The sections were then washed and mounted in PBS/glycerol as usual. The stained sections were viewed under epifluorescence UV illumination on a Leitz Orthoplan microscope (equipped with an HBO 200 mercury lamp) at $1000 \times$ magnification and appropriate filter combinations for FITC (I2) and Hoechst 33258 (A).

\section{Results}

\section{Identification of cell types present in quail DRG early during development}

The proportions of neurons, glial cells, and fibroblasts were determined in short-term cultures of dissociated DRG using the O4 antigen as a marker for glial cells, the Q211 antigen and tetanus toxin receptors as markers for neurons, and fibronectin as a marker for fibroblasts and endothelial cells as described previously (Rohrer et al., 1985). The proportion of neurons increased between E5 and E6 during the period of neuronal birth (Fig. 1). The percentage of neurons decreased after E6. This is partly due to neuronal death and also to the large increase in the number of glial cells per ganglion. The proportion of fibronectin-positive cells remained relatively constant between E5 and E14 (Fig. 1B). At E5, a population of undifferentiated cells was observed that was devoid of all markers. This population of cells disappeared at later developmental stages (after E6-E7), when $100 \%$ of DRG cells could be accounted for by neurons, glial cells, and fibroblasts.

\section{Precursor cells for adrenal chromaffin cells in quail DRG dem- onstrated by transplantation}

\section{Transplantation of intact DRG}

Since the cellular composition of quail DRG changes considerably during development, it was of interest to test ganglia of different ages for the presence of precursors for adrenal chromaffin cells by back-transplantation. Quail DRG were implanted into the neural crest migration pathway between neural tube and somites at the level of the 19 th to 23 rd somite of 2 -d-old chick embryos. Either 11 or $12 \mathrm{~d}$ after the implantation, the suprarenal gland was removed from the embryo and sectioned. Quail and chick cells were identified in frozen $5 \mu \mathrm{m}$ sections by their characteristic nuclear structure which was visualized by staining the DNA with a fluorescent dye (Fig. 2). Chromaffin cells were identified by indirect immunofluorescence using monoclonal antibodies against rat TH. We have developed and characterized for this purpose a mouse monoclonal antibody (Mab) directed against rat pheochromocytoma TH (see Materials and Methods). This Mab shows extensive species crossreactivity, recognizing a single protein of the appropriate molecular weight $(56-60,000)$ on immunoblots of total adrenal protein from quail, chick, rat, and bovine adrenal (Fig. 3). Adrenergic sympathetic neurons and adrenal chromaffin cells were identified in sections of chick and quail embryos at all stages investigated (E7-E16). Nuclear staining and TH immunofluorescence can be observed on the same cell by changing the filter combination (Fig. 2). The changing outline of the nucleus and its surrounding cytoplasm at different planes of focus allows the unequivocal assignment of a nucleus to its TH-stained cytoplasm.

Following back-transplantation of quail DRG from E4 to E8, quail cells could be identified in the suprarenal gland in a high proportion of operated embryos. DRG from E4, E5, and E6 DRG gave rise to TH-positive quail cells (Fig. 4, Table 1); however, no TH-positive cells were observed after implantation of DRG from 8-d-old quail embryos (Table 1). The absence of TH-positive quail cells after implantation of older ganglia was
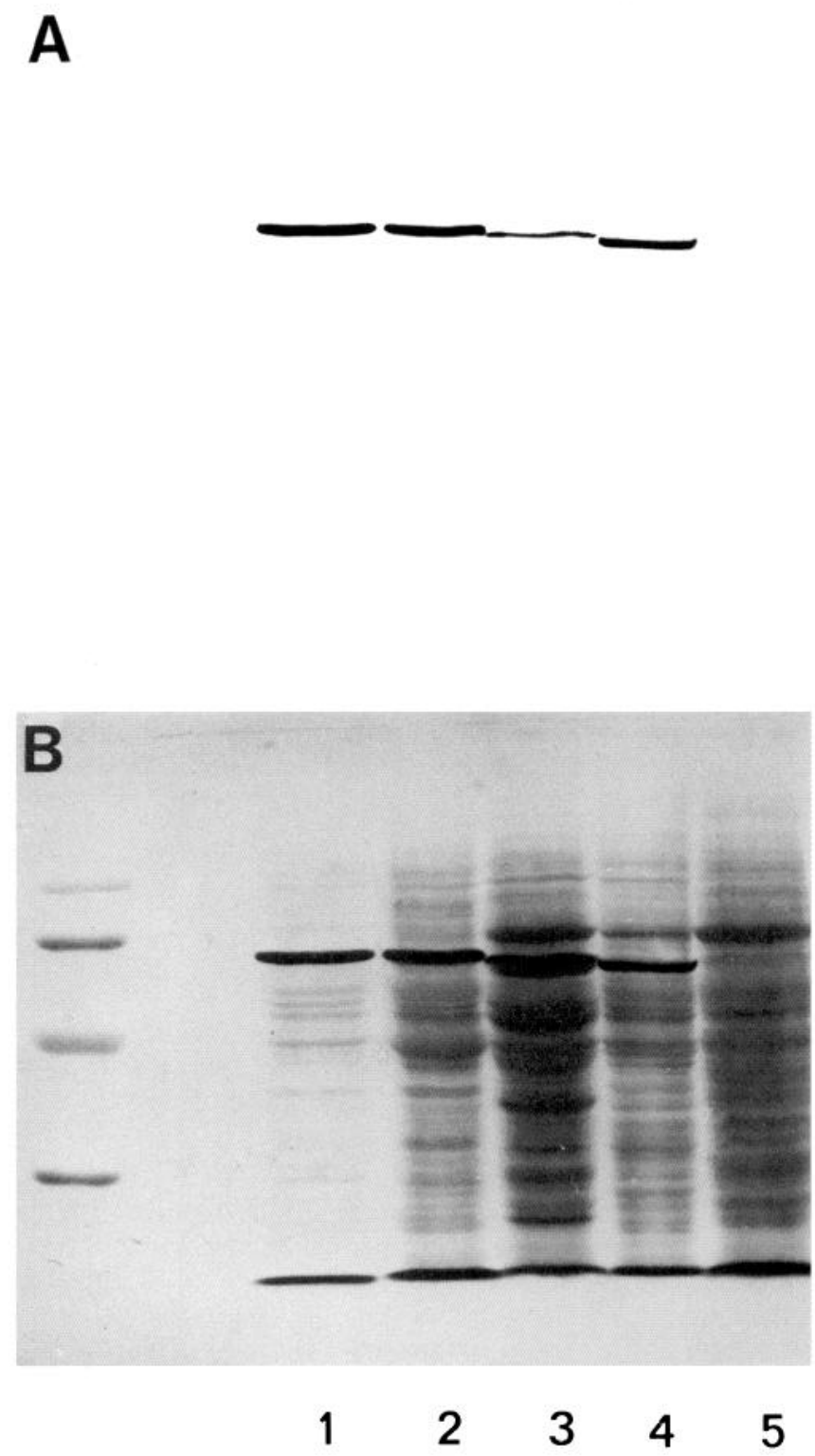

Figure 3. Specificity of monoclonal antibody $2 / 40 / 15$ analyzed by immunoblotting. Tissue homogenates were subjected to SDS-PAGE, transferred to nitrocellulose paper, and incubated with hybridoma supernatant. The immunoreactive bands and the protein pattern were identified as described in Materials and Methods. $A$, Immunoblot reacted with TH antibodies. $B$, Immunoblot reacted with TH and stained for proteins. Lanes 1-5 represent homogenates of quail (I), chicken (2), rat (3), and bovine (4) adrenal gland, and rat kidney (5). Molecularweight standards (stained for protein) were phosphorylase b $(94,000)$, albumin $(67,000)$, ovalbumin $(43,000)$, and carbonic anhydrase $(30,000)$.

not due to the inability of quail cells in general to migrate to the adrenal medulla, but rather to the absence of the specific cell type that is able to differentiate to chromaffin cells. Since the usual proportion of TH-positive cells was found in the experimental animals, it seems unlikely that the failure to detect TH-positive quail cells was due to a lack of sensitivity of the method used.

Transplantation of dissociated cell populations: Plasma clot technique

In order to back-transplant defined populations of dissociated cells, a technique had to be developed that allowed several thou- 

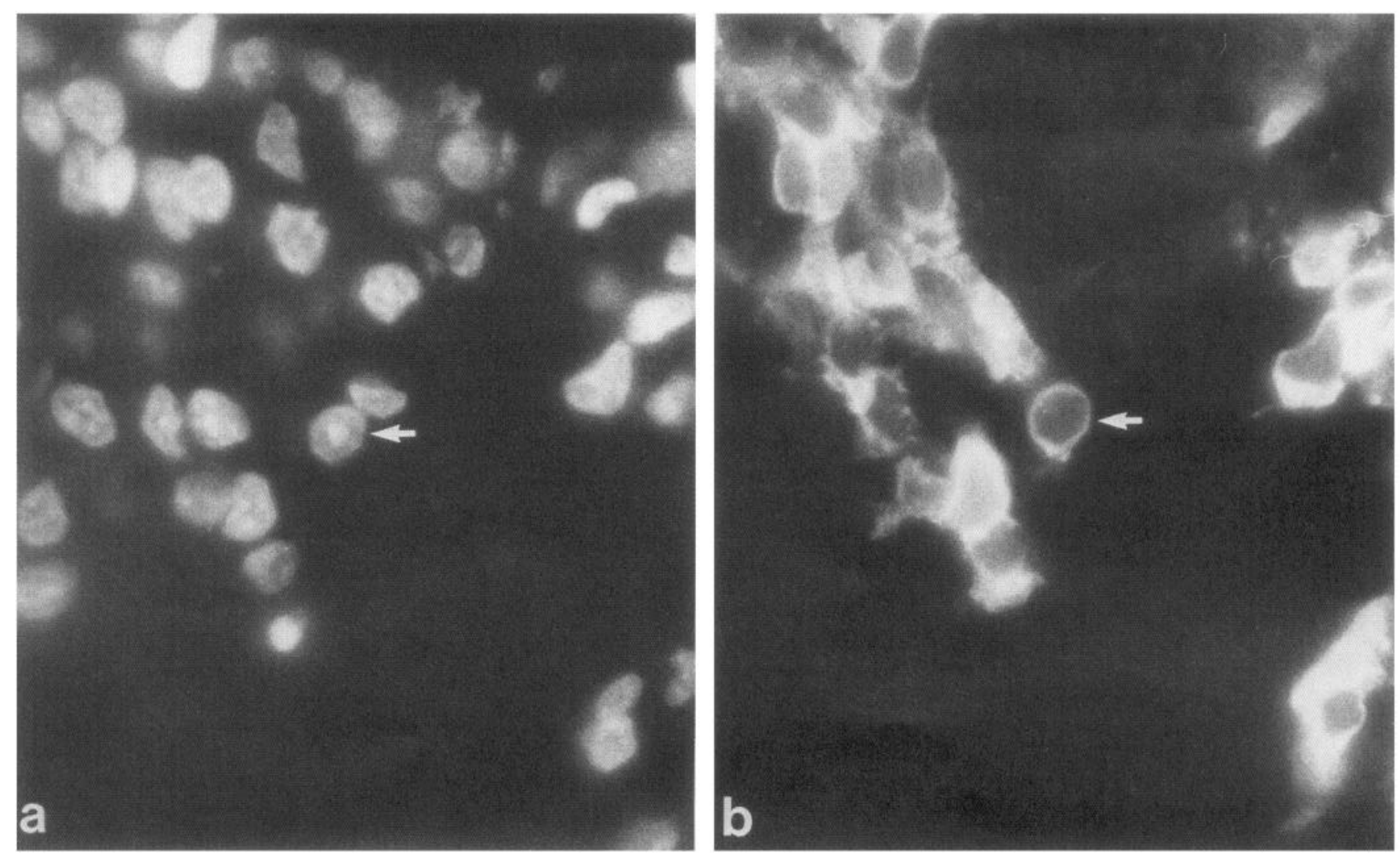

Figure 4. Identification of a TH-positive quail cell in the adrenal gland of a chick host after transplantation of E5 DRG. Frozen sections from the host adrenal gland were stained as described in Figure 3. Arrows indicate a TH-positive cell with a quail nucleus surrounded by chick adrenal cells: $a$, DNA staining; $b$, TH staining. Magnification, $\times 1300$.

sand cells to be handled in a manner similar to that used for ganglia, i.e., a method permitting them to be implanted into the host embryo while also still being able to migrate out after implantation. All these requirements were met by the technique of embedding a pellet of dissociated cells into a plasma clot which could then be cut to the appropriate size and implanted easily, and which also allowed the subsequent migration of the cells out of the plasma clot. The last point was checked routinely after all plasma clot implantations by culturing pieces of the plasma clot as explants. Explants of plasma clot-embedded cells and explants of ganglia are in most cases indistinguishable after $1-2 \mathrm{~d}$ in culture. Sometimes a small piece of plasma clot remains visible (Fig. $5 C$ ). In transplantation experiments, identical results were obtained when ganglia were implanted directly and when ganglia were dissociated and embedded in plasma clot before implantation (Table 1).

\section{Transplantation of undifferentiated cells from E5 DRG}

Chromaffin cell precursors were found in DRG at embryonic stages when undifferentiated cells were still present in the ganglia. We tried to directly prove that these cells (or a subpopulation of these cells) were able to differentiate to chromaffin cells by implanting these cells into young chick embryos.

Using the cell-type-specific antibodies Q211 and O4 in the presence of complement, neurons and/or glial cells can be eliminated from the total cell population present after dissociation of the ganglia (Rohrer et al., 1985) by a complement-mediated cytotoxic kill. Cell populations devoid of neurons (Q211-kill), devoid of glial cells (O4-kill), or devoid of both neurons and glial cells (Q211- and O4-kill) were obtained from freshly dissociated DRG. These purified subpopulations were then embed- ded in plasma clots and implanted. Under all conditions, THpositive quail cells were detected in the host embryo (Table 2), proving that the undifferentiated cell population contains precursors for adrenal chromaffin cells. Since the proportion of THpositive quail cells was reduced after Q211-kill and after O4kill, the possibility cannot be excluded that immature neurons and glial cells are also able to differentiate to the adrenergic phenotype. It is, however, more likely that this reduction is due to secondary effects of cell debris in the plasma clot after the complement-mediated cell lysis. The latter assumption is supported by the finding that the survival of nerve cells that differentiate from neuronal progenitor cells in the undifferentiated cell population in vitro (see below) is drastically impaired in the presence of cell debris after complement-mediated cell lysis (U. Ernsberger and H. Rohrer, unpublished observations).

\section{The undifferentiated cell population in vitro}

The undifferentiated cell population from E5 quail DRG, obtained by complement-mediated elimination of neurons and glial cells as described above, contained neuronal progenitor cells that differentiated in vitro to nerve cells, as characterized by their morphology and their cell-type-specific surface markers (Fig. 6). The number of Q211-positive cells per dish increased between 3 and $18 \mathrm{hr}$ in culture by a factor of $5 \pm 2$. We have recently shown for neuronal progenitor cells in chick DRG that the newly differentiated neurons also express voltage-dependent sodium and calcium channels after about $1 \mathrm{~d}$ in culture (Rohrer et al., 1985). About 30\% of the undifferentiated cell population differentiates to neurons. Preliminary experiments indicate that these neurons do not display the adrenergic phenotype (U. Ernsberger and $\mathrm{H}$. Rohrer, unpublished observations). 
Table 1. Transplantation of quail DRG from E5-E8 embryos

\begin{tabular}{llll}
$\begin{array}{l}\text { Tissue } \\
\text { or cells } \\
\text { implanted }\end{array}$ & $\begin{array}{l}\text { Embryos with } \\
\text { quail cells in } \\
\text { the adrenal } \\
\text { medulla }\end{array}$ & $\begin{array}{l}\text { Total number } \\
\text { of quail cells } \\
\text { analyzed }\end{array}$ & $\begin{array}{l}\text { Percentage of } \\
\text { quail cells } \\
\text { with TH }\end{array}$ \\
\hline E4 DRG & $4 / 4$ & 139 & 36 \\
E5 DRG & $4 / 5$ & 109 & 32 \\
E5 DRG & $5 / 5$ & 198 & 32 \\
E6 DRG & $4 / 4$ & 140 & 14 \\
E8 DRG & $9 / 10$ & 298 & 0 \\
E8 DRG & $11 / 15$ & 272 & 0
\end{tabular}

The results in column 2 are expressed as the ratio of embryos that contained quail cells in the adrenal medulla to the total number of embryos analyzed. PC, Dissociated DRG cells were embedded in plasma clot and implanted.

\section{Discussion}

It has previously been shown that a population of undifferentiated cells as defined by the absence of surface markers specific for neurons, glia, or fibroblasts is present in dissociates of E5E7 chick DRG (Rohrer et al., 1985). It was suggested that these undifferentiated cells may represent precursor cells that have the potential to differentiate into an adrenergic, i.e., non-DRG, phenotype. In order to test this hypothesis using the back-transplantation technique, we have first established that the undifferentiated subpopulation of cells is also present in quail DRG. These cells were found to be present until E6, after which time all cells could be accounted for by neuron-, glia-, or fibroblastspecific surface markers. This occurs about $1 \mathrm{~d}$ earlier than in the chick, which is in good agreement with the birthdates of peripheral neurons in the quail, which are about $1 \mathrm{~d}$ earlier than in the chick (Dupin, 1984). The fact that virtually all cells express differentiated properties after E6 indicates that the large increase in glial cell number which occurs later during development (Pannese, 1969, 1974) is thus due to the division of O4 positive cells, rather than to differentiation of O4-negative glia precursor cells.

The back-transplantation technique developed by LeDouarin and collaborators (LeDouarin et al., 1978; LeLievre et al., 1980) allowed the analysis of the potential of cells in quail DRG to differentiate to adrenergic phenotypes. By transplanting DRG of different ages and cellular composition, conclusions could be drawn about the subpopulation of cells that is able to differentiate to adrenergic cells. Whereas after transplantation of E5 DRG many TH-positive chromaffin cells developed in the host suprarenal gland, we could not detect any TH-positive quail chromaffin cell after transplantation of E8 DRG. These results suggest that immature O4-positive cells, which are present at E8 in chick DRG (and in quail DRG, unpublished results) and which have been considered previously as adrenergic precursor cells (Rohrer, 1985) since they express noradrenaline uptake and NGF receptors, are unable to differentiate to chromaffin cells. Rather, the correlation between the time of disappearance of chromaffin cell precursors and of undifferentiated cells in DRG during development suggests that these undifferentiated cells are the precursors for chromaffin cells. Indeed, when this hypothesis was tested directly by back-transplantation of the undifferentiated cells (O4 + Q211-killed) from E5 DRG, many TH-positive quail cells were observed in the host adrenal, supporting the concept that undifferentiated cells can express the adrenergic phenotype.

The elimination of glial cells (O4-kill) and of neurons (Q-kill) before implantation reduced the proportions of quail cells that acquire TH immunoreactivity after transplantation. This reduction was most likely due to secondary effects of cell debris in the plasma clot after cell lysis by complement. However, it
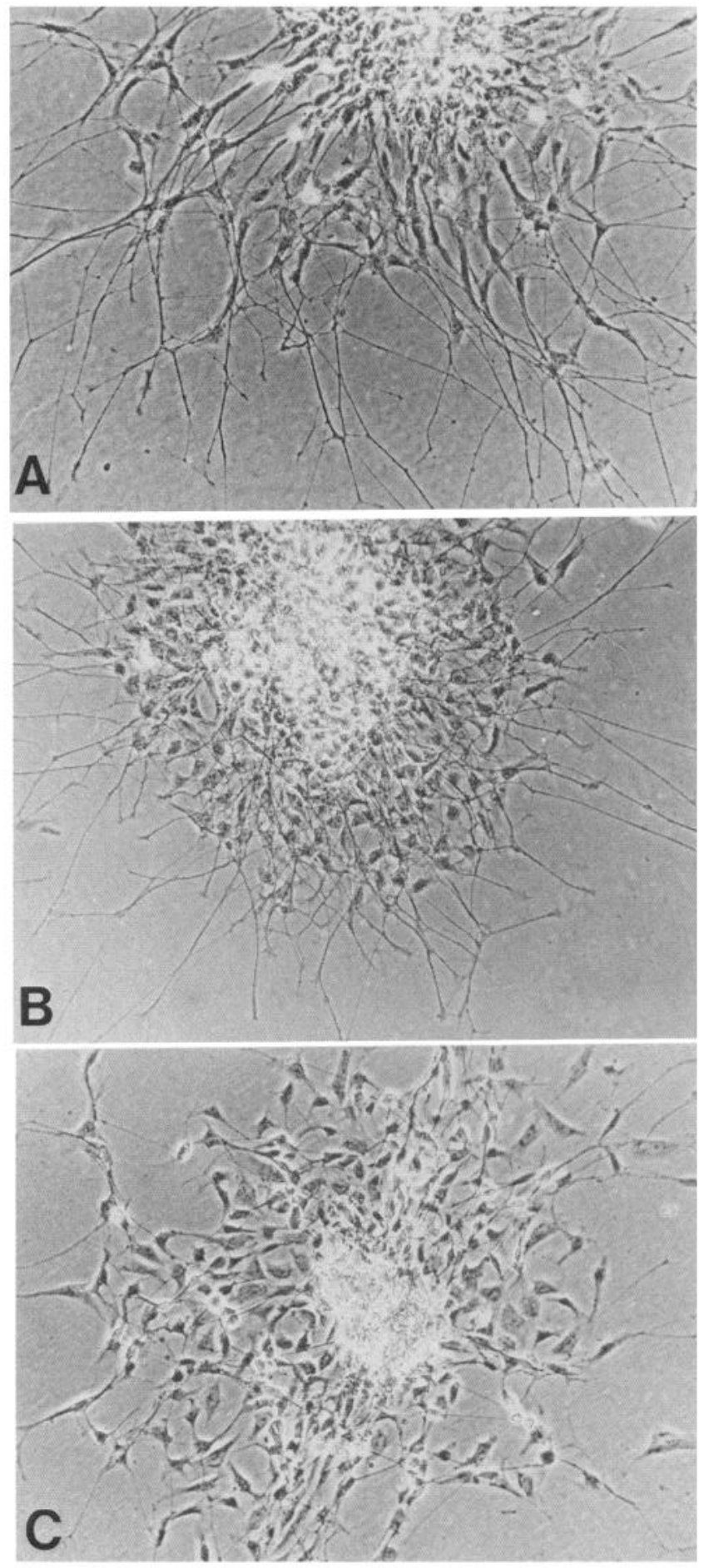

Figure 5. Explant cultures of intact E5 DRG and E5 DRG cell subpopulations embedded in plasma clot. E5 DRG $(A)$ and pieces of plasma clot that contained dissociated E5 DRG cells $(B)$ or E5 DRG cells after complement-mediated elimination of neurons and glial cells $(C)$ were cultivated for $1 \mathrm{~d}$ on collagen-coated dishes as described in Materials and Methods. Note the remaining phase-bright piece of plasma clot in C. Magnification, $\times 130$.

is possible that, at E5, immature neurons and glial cells are also able to differentiate to chromaffin cells. This question could be answered by implanting pure neuronal or glial populations from E5 DRG, but so far it has not been possible to select neuronal or glial cells devoid of undifferentiated cells. 

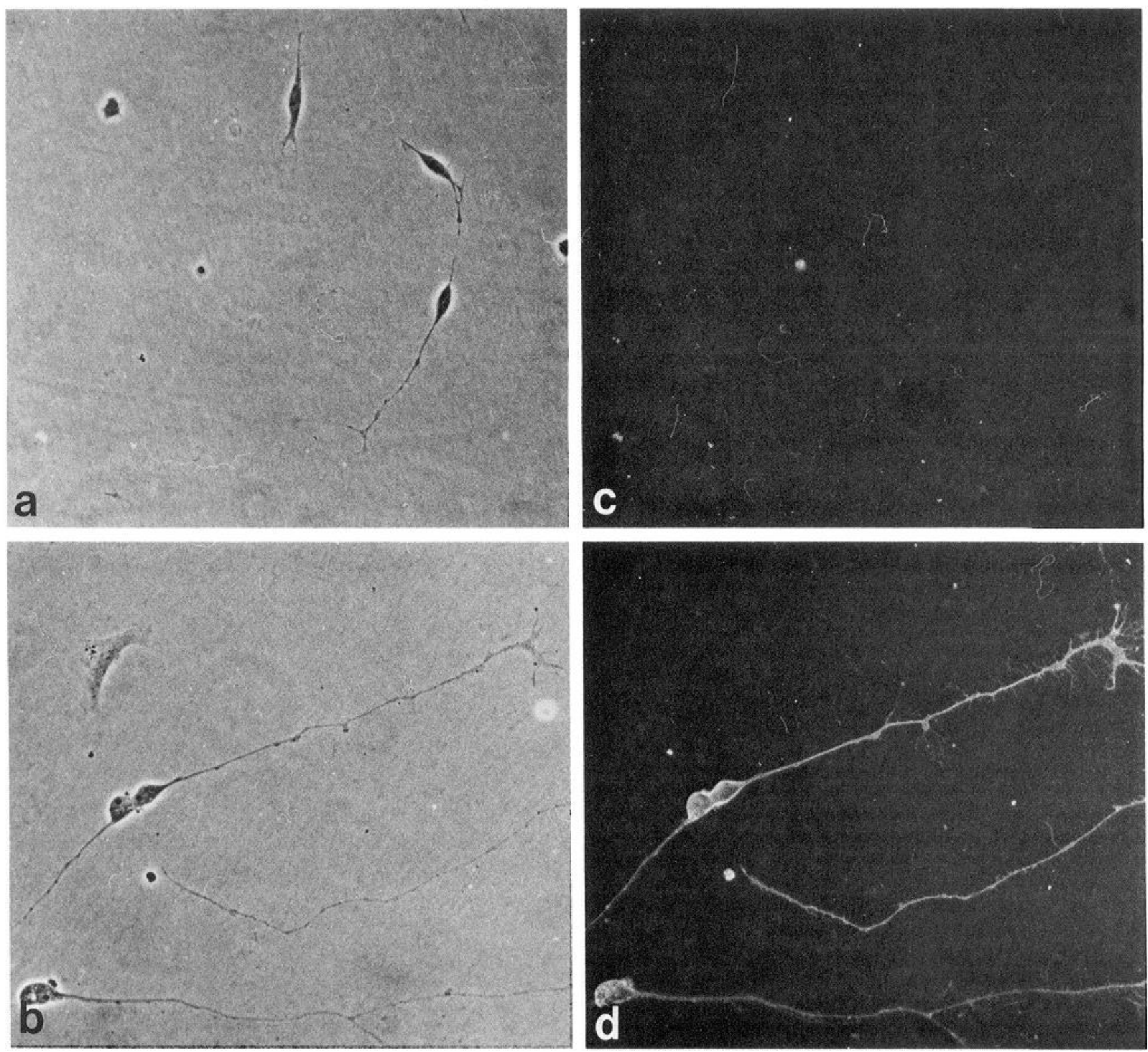

Figure 6. Differentiation of neuronal progenitor cells in vitro. E5 DRG cell suspensions were treated with complement, Q211 antibody, and O4 antibody; plated on dishes coated with polyornithine and laminin; and analyzed for the appearance of Q211 antigen-positive cells after 3 hr ( $a$, $c$ ) and $1 \mathrm{~d}(b, d) . a$ and $b$, Phase contrast; $c$ and $d$, FITC fluorescence for Q211 antigen. Magnification, $\times 270$.

After having established the presence of chromaffin cell precursors in the undifferentiated subpopulation of quail DRG cells, we have characterized the cell types that develop in vitro. Under the specific culture conditions used, about $30 \%$ of the cells underwent rapid morphological differentiation to neurons. This differentiation was characterized by a neuronal morphology (round, phase-bright cell body, long neurites) and by the presence of neuron-specific cell-surface antigens (Q211, tetanus toxin). Such neuronal precursor cells, i.e., Q211 antigen-negative cells that differentiate to Q211+ cells with neuronal morphology within $1 \mathrm{~d}$, were present in high numbers at E5 but were absent at E8. Thus, both neuronal precursor cells, as defined by in vitro differentiation, and adrenal chromaffin cell precursors, as defined by in vivo differentiation in back-transplantation studies, are present in significant numbers only during early development and disappear simultaneously. This may indicate that the same cell can undergo both differentiation processes.
The potential of DRG cells to differentiate to adrenergic cells after transplantation has been analyzed previously (LeLievre et al., 1980; Schweizer et al., 1983). It has been shown that DRG contain autonomic precursor cells that migrate to the adrenal gland and to the sympathetic chain ganglia where they differentiate to chromaffin cells and sympathetic neurons, respectively. Until E10 and later, quail DRG were found to contain cells that migrate to the sympathetic chain and differentiate to adrenergic, catecholamine-containing neurons. In the initial phase of the present study, the properties of quail cells that migrate into the host sympathetic chain ganglia were analyzed after back-transplantation of E4-E6 quail DRG. In this series of transplantations, many quail cells were detected in E13 sympathetic ganglia, but these quail cells were neither stained with antibodies against TH nor by antibodies against vasoactive intestinal peptide (Fontaine-Perus et al., 1982). A possible explanation for such a discrepancy would be that these cells express 
Table 2. Transplantation of different cell populations from E5 quail DRG

\begin{tabular}{lcll} 
Tissue or cells implanted & $\begin{array}{l}\text { Embryos with } \\
\text { quail cells in the } \\
\text { adrenal medulla }\end{array}$ & $\begin{array}{l}\text { Total number of } \\
\text { quail cells analyzed }\end{array}$ & $\begin{array}{l}\text { Percentage of } \\
\text { quail cells } \\
\text { with TH }\end{array}$ \\
\hline E5 DRG & $4 / 5$ & 109 & 32 \\
E5 DRG & $5 / 5$ & 198 & 32 \\
E5 DRG $_{\mathrm{PC}}$, Q211-killed & $9 / 9$ & 325 & 15 \\
E5 DRG $_{\mathrm{PC}}$, O4-killed & $6 / 6$ & 261 & 19 \\
E5 DRG & $13 / 15$ & 520 & 16
\end{tabular}

DRG or DRG cells from dissociated DRG embedded in plasma clot (PC) were implanted into 2-d-old chick embryos and analyzed for the presence of TH-positive quail cells in the host adrenal gland. Where indicated, Q211-positive neurons and/or O4-positive glial cells were eliminated from the E5 DRG cell population before embedding in plasma clot.

only some of the properties of adrenergic neurons, such as the ability to take up and to store norepinephrine, but not TH. It has been shown previously that some adrenergic traits, such as norepinephrine uptake, can be expressed by cells in the absence of other adrenergic properties (Kimelberg and Pelton, 1982; Landis and Keefe, 1983; Reichardt and Patterson, 1977; Rohrer and Sommer, 1983; see also Teitelman et al., 1985).

With respect to the DRG cells migrating to the adrenal gland and differentiating to chromaffin cells, the results of the present study agree with those of Schweizer et al. (1983), who also described a decrease in the number of quail chromaffin cells when DRG of older embryos were implanted. Concerning the time of disappearance of chromaffin cell precursors, it has to be pointed out that under transplantation conditions, precursor cell populations are able to expand by division (Dupin, 1984), and thus a clone of a single cell might be detected. This will give rise to a considerable variation in the results when the numbers of precursor cells are small. It also explains the presence of THpositive adrenal chromaffin cells after transplantation of E6 DRG (Table 1), which contains very few undifferentiated cells (Fig. 1).

We have described 2 differentiation pathways of undifferentiated progenitor cells, the potential to differentiate in vitro to neurons, and the potential to differentiate to TH-positive adrenal cells in vivo. The number of progenitor cells defined by these criteria decreased drastically during development. Since we have shown that autonomic precursor cells are present in the undifferentiated cell population of E15 DRG, it will be of interest to define in vitro conditions favoring the differentiation of the precursor cells towards the adrenergic phenotype and to establish whether a common precursor exists for sensory and autonomic neurons.

\section{References}

Acheson, A. L., K. Naujoks, and H. Thoenen (1984) Nerve growth factor-mediated enzyme induction in primary cultures of bovine adrenal chromaffin cells: Specificity and level of regulation. J. Neurosci. 4: $1771-1780$.

Ayer-LeLievre, C. S., and N. M. LeDouarin (1982) The early development of cranial sensory ganglia and the potentialities of their component cells studied in quail-chick chimeras. Dev. Biol. 94: 291-310.

Barde, Y.-A., D. Edgar, and H. Thoenen (1980) Sensory neurons in culture: Changing requirements for survival factors during embryonic development. Proc. Natl. Acad. Sci. USA 77: 1199-1 203.

Barde, Y.-A., D. Edgar, and H. Thoenen (1982) Purification of a new neurotrophic factor from mammalian brain. EMBO J. 1: 549-553.

Dupin, E. (1984) Cell division in the ciliary ganglion of quail embryos in situ and after back-transplantation into the neural crest migration pathway of chick embryos. Dev. Biol. 105: 288-299.

Fontaine-Perus, J. C., M. Chanconie, and N. M. LeDouarin (1982) Differentiation of peptidergic neurones in quail-chick chimaeric embryos. Cell Differ. 11: 183-193.
Gooding, J. W. (1980) Antibody production by hybridomas. J. Immunol. Methods 39: 285-308.

Hawkes, R., E. Niday, and J. Gordon (1982) A dot-immunobinding assay for monoclonal and other antibodies. Anal. Biochem. 119: 142147.

Henke-Fahle, S. (1983a) Dissertation, Med. Fak. Tübingen.

Henke-Fahle, S. (1983b) Monoclonal antibodies recognize gangliosides in the chick brain. Neurosci. Lett. 14: 160.

Kimelberg, H. K., and E. W. Pelton (1983) High-affinity uptake of ${ }^{3} \mathrm{H}$-norepinephrine by primary astrocyte cultures and its inhibition by tricyclic antidepressants. J. Neurochem. 40: 1265-1270.

Laemmli, U. K. (1970) Cleavage of structural proteins during the assembly of the head of bactcriophage T4. Naturc 227: 680-685.

Landis, S. C., and D. Keefe (1983) Evidence for neurotransmitter plasticity in vivo: Developmental changes in properties of cholinergic sympathetic neurons. Dev. Biol. 98: 349-372.

LeDouarin, N. M. (1973) A biological cell labeling technique and its use in experimental embryology. Dev. Biol. 20: 217-222.

LeDouarin, N. M. (1984) A model for cell-lineage divergence in the ontogeny of the peripheral nervous system. In Cellular and Molecular Biology of Neuronal Development, I. Black, ed., pp. 3-26, Plenum, New York.

LeDouarin, N. M., M. A. Teillet, C. Ziller, and J. Smith (1978) Adrenergic differentiation of cells of the cholinergic ciliary and Remak ganglia in avian embryo following in vivo transplantation. Proc. Natl. Acad. Sci. USA 75: 2030-2034.

LeLievre, C. S., G. G. Schweizer, C. M. Ziller, and N. M. LeDouarin (1980) Restrictions of developmental capabilities in neural crest derivatives as tested by in vivo transplantation experiments. Dev. Biol. 77: 362-378.

Pannese, E. (1969) Electron microscopical study on the development of the satellite cell sheath in spinal ganglia. J. Comp. Neurol. 135: $381-422$.

Pannese, E. (1974) The histogenesis of the spinal ganglia. Adv. Anat. Embryol. Cell Biol. 47: 6-97.

Patterson, P. H. (1978) Environmental determination of autonomic neurotransmitter function. Annu. Rev. Neurosci. 1: 1-17.

Rcichardt, L. F., and P. H. Patterson (1977) Ncurotransmitter synthesis and uptake by isolated sympathetic neurones in microcultures. Nature 270: 147-151.

Rohrer, H. (1985) Nonneuronal cells from chick sympathetic and dorsal root sensory ganglia express catecholamine uptake and receptors for nerve growth factor during development. Dev. Biol. 111: 95107.

Rohrer, H., and I. Sommer (1983) Simultaneous expression of neuronal and glial properties by chick ciliary ganglion cells during development. J. Neurosci. 3: 1683-1693.

Rohrer, H., J. Thibault, and S. Henke-Fahle (1984) Neuronal precursor cells in the chick sensory dorsal root ganglion during development. Biol. Chem. Hoppe-Seyler 366: 141.

Rohrer, H., S. Henke-Fahle, T. El-Sharway, H. D. Lux, and H. Thoenen (1985) Progenitor cells from embryonic chick dorsal root ganglia differentiate in vitro to neurons: Biochemical and electrophysiological evidence. EMBO J. 4: 1709-1714.

Schweizer, G., C. Ayer-LeLievre, and N. M. LeDouarin (1983) Re- 
strictions of developmental capacities in the dorsal root ganglia during the course of development. Cell Differ. 13: 191-200.

Sommer, I., and M. S. Schachner (1981) Monoclonal antibodies (O1 to O4) to oligodendrocyte cell surfaces: An immunocytological study in the central nervous system. Dev. Biol. 83: 311-327.

Teitelman, G., T. H. Joh, L. Grayson, D. A. Park, D. J. Reis, and L. lacovitti (1985) Cholinergic neurons of the chick ciliary ganglia express adrenergic traits in vivo and in vitro. J. Neurosci. 5: 29-39.
Thibault, J., D. Vidal, and F. Gros (1981) In vitro translation of m-RNA from rat pheochromocytoma tumors, characterization of tyrosine hydroxylase. Biochem. Biophys. Res. Commun. 99: 960-968. Towbin, H., T. Staehelin, and J. Gordon (1979) Electrophoretic transfer of proteins from polyacrylamide gels to nitrocellulose sheets: Procedure and some applications. Proc. Natl. Acad. Sci. USA 76: 43504354. 